\title{
EKSTRAKSI DAN KARAKTERISASI PARSIAL EKSTRAK KASAR ENZIM KATEPSIN DARI IKAN PATIN
}

\author{
[Extraction and Partial Characterization of Crude Enzymes Cathepsin from Catfish]
}

\author{
Muhammad Zakiyul Fikri, Tati Nurhayati dan Ella Salamah \\ Departemen Teknologi Hasil Perairan, Fakultas Perikanan dan IImu Kelautan, Institut Pertanian Bogor, Bogor
}

Diterima 02 Juli 2013 / Disetujui 30 Mei 2014

\begin{abstract}
Decomposition of protein by enzymatic process will lead to changes in odor, texture, and appearance of fish. The enzymes that play a role in the enzymatic process is primarily proteolytic enzymes. Cathepsin is one of the proteolytic enzymes found in animal tissue that hydrolyzes peptide bonds of proteins. This study aims to extract the cathepsin, characterize the crude extract derived from catfish. The stages of this research consist of the extraction and characterization of the cathepsin from catfish. Result of the extraction was crude extract of cathepsin with activity of 0.278 $\mathrm{U} / \mathrm{mL}$. The enzyme had optimum temperature of $50^{\circ} \mathrm{C}, \mathrm{pH} 6$ and substrate concentration of $2 \%$. The activity of the cathepsin was inhibited by metal ions of $\mathrm{Fe}^{3+}, \mathrm{Cu}^{2+}, \mathrm{Ca}^{2+}$, but increased by metal ions of $\mathrm{Mg}^{2+}$.
\end{abstract}

Keywords: catfish, cathepsin, enzyme

\section{ABSTRAK}

Penguraian protein dalam proses enzimatis akan menyebabkan perubahan bau, tekstur, dan penampakan ikan. Enzim yang berperan dalam proses enzimatis terutama adalah enzim proteolitik. Enzim katepsin merupakan salah satu enzim proteolitik yang ditemukan pada jaringan hewan yang dapat menghidrolisis ikatan peptida pada protein. Penelitian ini bertujuan untuk mengekstraksi enzim katepsin dan mengkarakterisasi ekstrak kasar enzim katepsin yang berasal dari ikan patin. Tahapan penelitian terdiri dari proses ekstraksi dan karakterisasi. Hasil ekstraksi berupa ekstrak kasar enzim katepsin dengan aktivitas sebesar $0.278 \mathrm{U} / \mathrm{mL}$. Enzim tersebut memiliki suhu optimum $50^{\circ} \mathrm{C}$, pH optimum 6 , dan substrat optimum $2 \%$. Aktivitas ekstrak kasar enzim katepsin dihambat oleh ion logam $\mathrm{Fe}^{3+}, \mathrm{Cu}^{2+}, \mathrm{Mn}^{2+}, \mathrm{Ca}^{2}$, namun ditingkatkan oleh ion logam $\mathrm{Mg}^{2+}$.

Kata kunci: enzim, katepsin, ikan patin

\section{PENDAHULUAN}

Ikan patin merupakan salah jenis ikan budidaya yang memegang peranan penting dalam produksi perikanan budidaya yang mencapai nilai produksi pada tahun 2009 sebesar 109.606 ton (KKP, 2011). Selain nilai produksi yang cukup tinggi, ikan patin juga mempunyai kandungan gizi yang cukup untuk memenuhi kebutuhan protein hewani. Kandungan protein pada filet patin cukup tinggi, yaitu berkisar antara 12.94$17.52 \%(b b)$, sedangkan kandungan lemaknya berkisar antara $0.89-1.23 \%$ (bb). Kandungan lemak filet patin cukup rendah bila dibandingkan produk ikan lainnya. Pada ikan patin kandungan lemak yang tinggi terutama berasal dari bagian perut (belly) yaitu $54.43 \%$ (bk) (Thammapat et al. 2010).

Kandungan gizi ikan patin menjadi tidak bernilai tinggi apabila tidak ditangani dengan baik setelah penangkapan atau pemanenan. Hal ini disebabkan ikan patin sebagai bahan pangan sangat rentan terhadap kerusakan. Kerusakan ini dapat terjadi secara fisik, biokimiawi, maupun mikrobiologi. Kerusakan daging ikan yang terjadi pada fase rigor mortis hingga fase post rigor, ditandai dengan melemasnya daging ikan (softening).

*Penulis Korespondensi:

E-mail: zakifikrii@gmail.com
Proses penurunan mutu ikan segar terutama diawali dengan proses perombakan oleh aktivitas enzim yang secara alami terdapat di dalam ikan. Salah satu jenis enzim yang berperan penting dalam proses kemunduran mutu ikan adalah enzim proteolitik yang menguraikan protein menjadi pepton, peptida dan asam-asam amino. Hidrolisis protein oleh suatu protease seperti katepsin, calpain dan kolagenase dapat menyebabkan timbulnya akumulasi metabolit, perubahan citarasa dan pelunakan tekstur, terbentuknya komponen volatil serta peningkatan jumlah bakteri yang akhirnya menimbulkan kebusukan. Aktivitas proteolitik menyebabkan perubahan fungsional dan sifat organoleptik dari daging ikan. Katepsin merupakan kelompok dari sistein protease diantaranya katepsin $B$ dan $L$ yang dapat menyebabkan terjadinya pelunakan daging (softening) pada ikan (Ladrat et al. 2006).

Informasi mengenai enzim katepsin yang berasal dari ikan patin belum diketahui, sehingga perlu dilakukan penelitian mengenai karakteristik dari enzim katepsin yang menjadi salah satu faktor utama proses pembusukan ikan. Penelitian ini diharapkan dapat memberikan informasi mengenai karakteristik enzim katepsin yang berasal dari daging ikan patin. Informasi ini dapat dikelola agar pada saat penanganan kondisi-kondisi lingkungan yang dapat meningkatkan kerja enzim katepsin secara optimal khususnya pada ikan patin dapat dihindari. 


\section{BAHAN DAN METODE}

\section{Bahan}

Bahan yang digunakan terdiri dari bahan utama berupa ikan patin dalam keadaan post-rigor yang diperoleh dari pasar tradisional Bogor.

\section{Ekstraksi enzim katepsin}

Ekstraksi dilakukan dengan preparasi sampel untuk memperoleh ekstrak kasar protease katepsin. Daging ikan diambil dan disuspensikan dalam akuades dengan perbandingan daging ikan dan akuades sebesar 1:1, lalu dihomogenisasi pada suhu $0-4^{\circ} \mathrm{C}$. Proses selanjutnya adalah pemisahan dengan menggunakan sentrifugasi dingin (Beckmen) (Gambar 1).

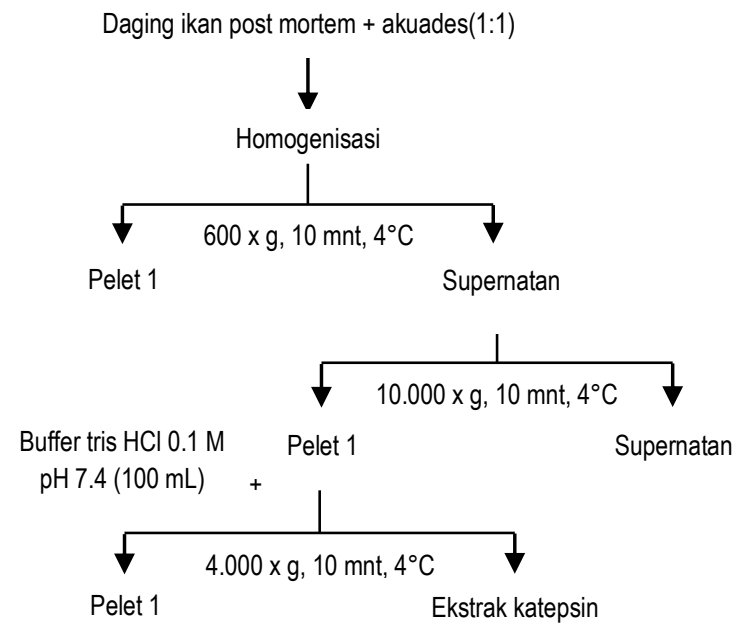

Gambar 1. Diagram alir proses ekstraksi enzim katepsin dengan teknik differensial sentrifugasi (Dinu et al. 2002)

Ekstrak daging hasil homogenisasi disentrifugasi pada 600 x $g$ selama 10 menit dan supernatan yang diperoleh kemudian disentrifugasi lagi pada 10.000 x g selama 10 menit. Pelet yang dihasilkan dari hasil sentrifugasi kemudian dilarutkan dalam 0.1 $\mathrm{M}$ buffer tris- $\mathrm{HCl}$ (Aplichem) $\mathrm{pH} 7.4$ dengan jumlah yang sama seperti jumlah akuades dan disentrifugasi pada $4.000 \times \mathrm{g}$ selama 10 menit. Hasil supernatan (ekstrak kasar protease katepsin) yang diperoleh merupakan protein utama dari mitokondria dan lisosom yang siap untuk diteliti aktivitasnya lebih lanjut.

\section{Aktivitas katepsin}

Aktivitas proteolitik dari katepsin diuji menggunakan hemoglobin (SIGMA-ALDRICH) sebagai substratnya dengan konsentrasi $2 \% \mathrm{pH}$ 2. Sebanyak $0.5 \mathrm{~mL}$ dari larutan substrat diinkubasi dengan inkubator (Thermoline type 42000) dengan $0.1 \mathrm{~mL}$ larutan enzim pada $37^{\circ} \mathrm{C}$ selama 10 menit. Reaksi dihentikan dengan penambahan $2 \mathrm{~mL}$ TCA (EMSURE) $5 \%$ (w/v). Campuran disaring dengan kertas saring Whatman no.1, dan hasil reaksi yang dapat larut ditambah dengan $1 \mathrm{~mL}$ pereaksi folin (Merck). Campuran kemudian diukur dengan spektrofotometer (Spectrophotometer UV-2500 Labomedlnc) pada panjang gelombang $750 \mathrm{~nm}$. Selain itu, dilakukan pula pengukuran untuk larutan blanko dan larutan standar dengan prosedur yang sama seperti larutan sampel, untuk larutan standar digunakan tirosin (Aplichem). Aktivitas katepsin diukur berdasarkan metode Dinu et al. (2002).

\section{Penentuan suhu optimum}

Karakterisasi ekstrak enzim katepsin dilakukan pada variasi suhu $40,50,60$ dan $70^{\circ} \mathrm{C}$. Pada waktu pengujian, hemoglobin sebagai substratnya dibuat dengan konsentrasi $2 \% \mathrm{pH} 2$. Aktivitas enzim katepsin kasar diukur berdasarkan metode Dinu et al. (2002).

\section{Penentuan pH optimum}

Karakterisasi $\mathrm{pH}$ dilakukan menggunakan substrat hemoglobin $2 \%$ yang diatur pada berbagai variasi $\mathrm{pH}$ yaitu 3,4 , 5, 6, dan 7 dengan $\mathrm{pH}$ meter (Orion 3STAR). Buffer Tris - $\mathrm{HCl}$ (Aplichem) yang digunakan juga diatur pada variasi $\mathrm{pH}$ yang sama yaitu 3, 4, 5, 6, dan 7. Aktivitas enzim katepsin diukur berdasarkan metode Dinu et al. (2002).

\section{Penentuan substrat optimum}

Karakterisasi konsentrasi substrat dilakukan dengan mengubah konsentrasi substrat hemoglobin dengan berbagai variasi konsentrasi yaitu : $0.5,1,1.5,2,2.5,3,3.5$ dan $4 \%$ (b/v) pada $\mathrm{pH}$ 2. Aktivitas enzim katepsin kasar diukur berdasarkan metode Dinu et al. (2002).

\section{Penghambatan ion logam}

Karakterisasi pengaruh ion logam dilakukan dengan menambahkan ion logam monovalent, bivalen dan trivalent pada waktu pengujian, hemoglobin sebagai substratnya dibuat dengan konsentrasi $2 \% \mathrm{pH}$ 2. Sebanyak $0.5 \mathrm{~mL}$ larutan substrat, $0.1 \mathrm{~mL}$ larutan buffer Tris $\mathrm{pH} 7.4$ dan $0.1 \mathrm{~mL}$ larutan logam $\left(\mathrm{NaCl}, \mathrm{CaCl}_{2}, \mathrm{ZnCl}_{2}, \mathrm{CuSO}_{4}, \mathrm{MgCl}_{2}, \mathrm{MnCl}_{2}\right.$ dan $\mathrm{FeCl}_{3}$ ) diinkubasi dengan $0.1 \mathrm{~mL}$ larutan enzim pada $37^{\circ} \mathrm{C}$ selama 10 menit. Reaksi dihentikan dengan penambahan $2 \mathrm{~mL}$ TCA (EMSURE) $5 \%(\mathrm{w} / \mathrm{v})$. Campuran disaring dan $1 \mathrm{~mL}$ filtrat hasil hasil penyaringan ditambah dengan $1 \mathrm{~mL}$ pereaksi folin (Merck). Selanjutnya diinkubasi kembali pada suhu $37^{\circ} \mathrm{C}$ selama 10 menit. Campuran kemudian diukur dengan spektrofotometer pada panjang gelombang $750 \mathrm{~nm}$ (Spectrophotometer UV-2500 Labomedlnc). Aktivitas enzim katepsin kasar diukur berdasarkan metode Dinu et al. (2002).

\section{Penentuan konsentrasi protein}

Konsentrasi protein ditentukan menggunakan metode Bradford (Bradford, 1976) dengan bovine serum albumin (Aplichem) sebagai standar. Konsentrasi protein ditentukan dengan cara $0.1 \mathrm{~mL}$ enzim dimasukkan ke dalam tabung reaksi. Kemudian ditambahkan sebanyak $5 \mathrm{~mL}$ pereaksi Bradford (Aplichem), diinkubasi selama lima menit dan diukur absorbansinya dengan spektrofotometer pada panjang gelombang $595 \mathrm{~nm}$. Demikian pula untuk larutan standar dilakukan sama seperti larutan sampel dengan konsentrasi antara 0.1-1.0 $\mathrm{mg} / \mathrm{mL}$. 


\section{HASIL DAN PEMBAHASAN}

Ekstrak kasar katepsin yang diperoleh dari daging ikan patin sudah memasuki tahap post-rigor memiliki aktivitas enzim sebesar $0.278 \mathrm{U} / \mathrm{mL}$, aktivitas spesifik $0.9073 \mathrm{U} / \mathrm{mg}$ dan kadar protein sebesar $0.3064 \mathrm{mg} / \mathrm{mL}$. Berdasarkan hasil penelitian Nurhayati et al. (2012) diketahui bahwa ekstrak kasar katepsin yang berasal dari ikan bandeng memiliki aktivitas spesifiknya sebesar $0.8598 \mathrm{U} / \mathrm{mg}$ dengan kadar protein sebesar 0.1163 $\mathrm{mg} / \mathrm{mL}$. Penelitian Toyohara et al. (2006) menyebutkan bahwa ekstrak kasar katepsin A yang berasal dari daging ikan mas memiliki aktivitas spesifik sebesar $0.279 \mathrm{U} / \mathrm{mg}$ Pada tahapan ekstraksi, pemilihan buffer Tris- $\mathrm{HCl}$ pH 7.4 dinilai sudah sesuai. Hal ini sesuai dengan pendapat dari Whitaker (1994) yang menyatakan bahwa ekstraksi enzim sebaiknya menggunakan buffer untuk mengontrol pH dekat dengan 7.5 dan kekuatan ion 0.1-0.5.

\section{Suhu optimum}

Suhu merupakan salah satu faktor yang dapat mempengaruhi aktivitas enzim, termasuk didalamnya adalah enzim katepsin. Hal ini disebabkan karena enzim merupakan biokatalisator yang tersusun dari protein. Struktur protein dapat berubah akibat adanya pengaruh suhu. Pengaruh suhu terhadap aktivitas enzim dapat dilihat pada Gambar 2.

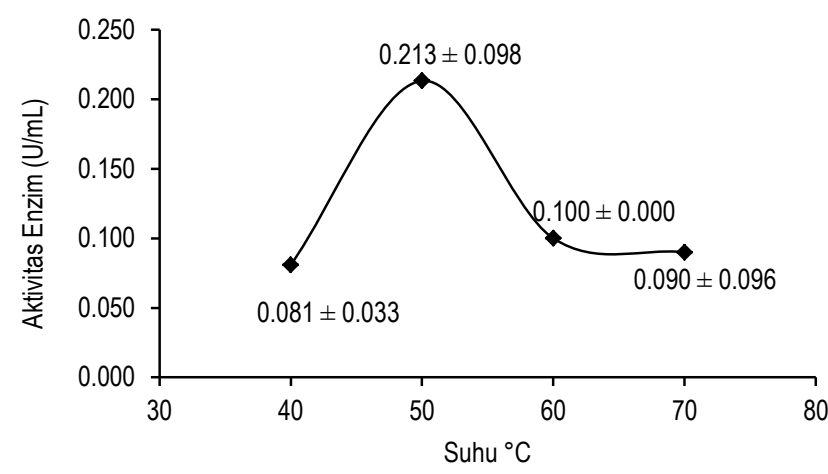

Gambar 2. Pengaruh suhu terhadap aktivitas enzim katepsin ikan patin

Ekstrak kasar enzim katepsin ikan patin memiliki aktivitas spesifik optimum pada suhu $50^{\circ} \mathrm{C}$ dengan nilai aktivitas sebesar $0.213 \mathrm{U} / \mathrm{mL}$. Beberapa hasil penelitian tentang katepsin yang berasal dari hasil perairan juga menyatakan suhu optimal enzim katepsin yang mendekati suhu optimal enzim katepsin dari ikan patin. Hasil penelitian Balti et al. (2010) terhadap katepsin D yang berasal dari hepatopankreas sotong memiliki aktivitas optimum pada $50^{\circ} \mathrm{C}$. Krause et al. (2010) menyatakan bahwa enzim katepsin $D$ yang berasal dari daging ikan ostrich memiliki aktivitas optimal pada suhu $45^{\circ} \mathrm{C}$. Hasil penelitian yang dilakukan oleh Liu et al. (2008) menunjukkan bahwa suhu optimum untuk enzim katepsin B1 pada silver carp $35^{\circ} \mathrm{C}$ sedangkan hasil penelitian yang dilakukan oleh Cunningham et al. (2010) menunjukkan bahwa enzim katepsin B pada ikan salmon memiliki suhu optimum sebesar $45^{\circ} \mathrm{C}$.

Suhu yang lebih tinggi akan membuat molekul lebih sering bertabrakan. Konsep ini berlaku juga untuk tumbukan antar molekul substrat dengan enzim. Hal ini disebabkan suhu yang tinggi akan mengkatalisis reaksi enzimatis. Namun, ketika kenaikan suhu melebihi titik tertentu akan menyebabkan gangguan terhadap struktur tersier enzim. Perubahan struktur tersier pada sisi aktif akan menghambat aktivitas katalitik enzim (Stoker, 2010).

\section{pH optimum}

Enzim memiliki aktivitas optimum pada $\mathrm{pH}$ tertentu. Hal ini terkait dengan sifat dasar protein yang dapat mengalami denaturasi akibat adanya pengaruh $\mathrm{pH}$.

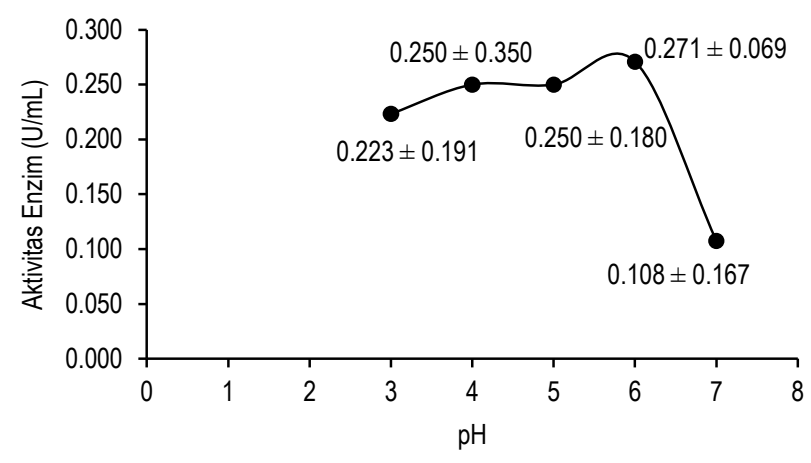

Gambar 3. Pengaruh $\mathrm{pH}$ terhadap aktivitas enzim katepsin ikan patin

Gambar 3 menunjukkan bahwa pH optimum untuk aktivitas enzim katepsin, yaitu pada $\mathrm{pH} 6$ dengan aktivitas $0.271 \mathrm{U} / \mathrm{mL}$. Aktivitas enzim katepsin meningkat dari pH 3 sampai pH 5 dan tertinggi pada $\mathrm{pH} 6$ kemudian menurun pada $\mathrm{pH} 7$. Zhong et al. (2012) melaporkan bahwa enzim katepsin $L$ yang diperoleh dari daging ikan blue scad mempunyai optimum pada $\mathrm{pH} 5.5$, hasil serupa juga dilaporkan oleh Chen dan Sun (2012) yang memperoleh katepsin B dari lidah ikan Cynoglossussemilaevis mempunyai $\mathrm{pH}$ optimum pada nilai 5.5 .

Hasil penelitian lainnya yang dilakukan oleh Cunningham et al. (2010) pada ikan salmon menghasilkan bahwa nilai pH optimum katepsin B sekitar pH 4. Berdasarkan hasil penelitian tersebut dapat dilihat bahwa enzim katepsin yang diekstrak dari ikan patin memiliki ciri-ciri enzim katepsin yang hampir sama dengan katepsin B1 ataupun katepsin B2 yang memiliki pH optimum berkisar 5.5-6.0; sedangkan katepsin B1 sekitar 5.0.

Semua reaksi enzim dipengaruhi oleh $\mathrm{pH}$ medium tempat reaksi terjadi. Setiap enzim memiliki pH optimum yang khas, yaitu $\mathrm{pH}$ yang menyebabkan aktivitas maksimal. Profil aktivitas $\mathrm{pH}$ enzim menggambarkan $\mathrm{pH}$ pada saat pemberi dan penerima proton yang penting pada sisi katalitik enzim berada pada tingkat ionisasi yang diinginkan. Namun pada $\mathrm{pH}$ tertentu (ekstrim) dapat menyebabkan enzim terdenaturasi yang menyebabkan enzim kehilangan aktivitas biologisnya (Lehninger, 1993).

\section{Konsentrasi substrat optimum}

Konsentrasi substrat merupakan salah satu faktor yang berpengaruh terhadap jumlah produk yang dihasilkan. Substrat dibutuhkan oleh enzim untuk berikatan dengan sisi aktif enzim sehingga akan terbentuk produk. Pengaruh susbtrat terhadap aktvitas enzim dapat dilihat pada Gambar 4. 


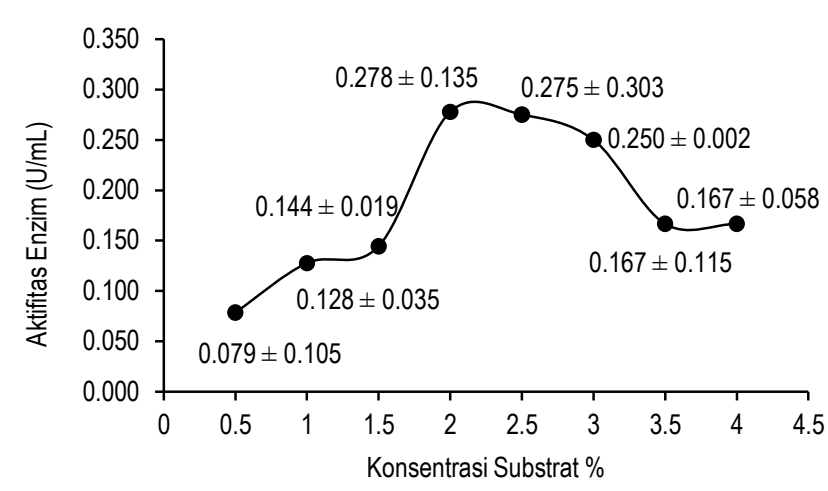

Gambar 4. Pengaruh konsentrasi substrat terhadap aktivitas enzim katepsin ikan patin

Gambar 4 menunjukkan bahwa aktivitas katepsin ikan patin optimum pada konsentrasi substrat $2 \%$ dengan aktivitas sebesar $0.278 \mathrm{U} / \mathrm{mL}$. Semakin banyak molekul substrat yang tersedia, semakin sering molekul-molekul tersebut memasuki sisi aktif molekul enzim. Akan tetapi, terdapat keterbatasan dalam memacu kecepatan reaksi dengan cara menambahkan lebih banyak lagi substrat ke suatu konsentrasi enzim yang tetap. Pada suatu titik tertentu, konsentrasi substrat itu akan menjadi cukup tinggi sehingga semua sisi aktif pada semua molekul enzim sudah ditempati oleh substrat. Segera setelah produk meninggkalkan sisi aktif, molekul substrat yang lain akan masuk. Pada konsentrasi substrat seperti ini, enzim itu dikatakan mengalami kejenuhan, dan laju reaksi ditentukan oleh kecepatan sisi aktif mengubah substrat menjadi produk. Ketika suatu enzim telah jenuh, satu-satunya cara untuk meningkatkan produktivitas ialah menambahkan lebih banyak lagi enzim (Campbell, 2002).

\section{Pengaruh ion logam terhadap aktivitas enzim}

Aktivator dan inhibitor secara kimiawi tidak dapat dibedakan. Namun dapat dibedakan setelah berinteraksi dengan enzim. Aktivator berikatan dengan enzim dan menyebabkan kenaikan kecepatan reaksi enzim, sedangkan inhibitor berikatan dengan enzim dan menyebabkan penurunan kecepatan reaksi (Suhartono, 1989). Pengaruh ion logam terhadap aktivitas enzim katepsin sebagaimana tertera pada Gambar 5.

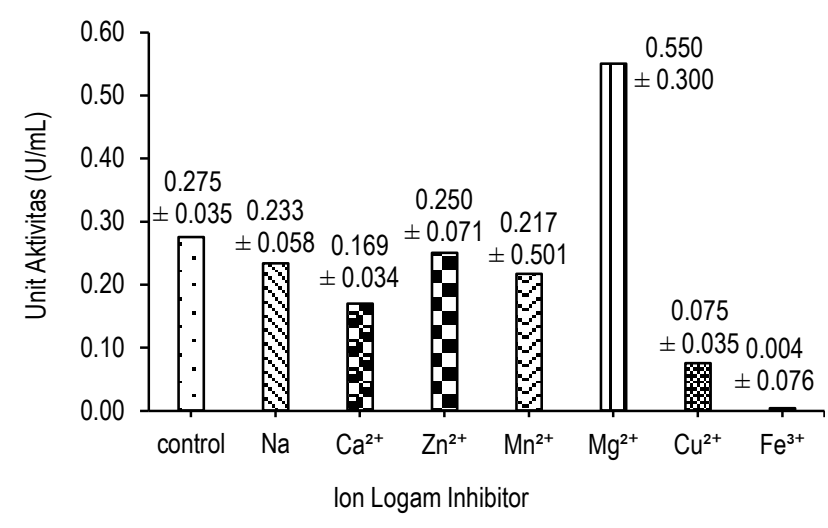

Gambar 5. Pengaruh ion logam konsentrasi $5 \mathrm{mM}$ terhadap aktivitas enzim katepsin
Berdasarkan Gambar 5 dapat dilihat bahwa ion logam $\mathrm{Cu}^{2+}$, $\mathrm{Ca}^{2+}, \mathrm{Mn}^{2+}$ dan $\mathrm{Fe}^{3+}$ dapat menjadi penghambat aktivitas enzim. Ion logam $\mathrm{Fe}^{3+}$ memberikan nilai penghambatan yang paling besar. Perbandingan nilai control aktivitas enzim dengan nilai aktivitas enzim yang telah ditambahkan ion logam dapat dilihat pada Tabel 1.

Tabel 1. Efek penambahan ion logam terhadap aktivitas enzim katepsin

\begin{tabular}{cc} 
katepsin & Relatif Activity $(\%)$ \\
\hline Konsentrasi Logam (5 mM) & 100 \\
Kontrol & 85 \\
$\mathrm{Na}$ & 62 \\
$\mathrm{Ca}^{2+}$ & 91 \\
$\mathrm{Zn}^{2+}$ & 79 \\
$\mathrm{Mn}^{2+}$ & 200 \\
$\mathrm{Mg}^{2+}$ & 27 \\
$\mathrm{Cu}^{2+}$ & 1 \\
$\mathrm{Fe}^{3+}$ &
\end{tabular}

Balti et al. (2010) menyatakan bahwa keberadaan ion logam $\mathrm{Mg}^{2+}, \mathrm{Ni}^{2+}, \mathrm{Zn}^{2+}, \mathrm{Cu}^{2+}, \mathrm{Cd}^{2+}, \mathrm{Sr}^{2+}$, and $\mathrm{Co}^{2+}$ akan meningkatkan aktivitas enzim katepsin $D$ yang berasal dari hepatopankreas sotong. Sementara keberadaan ion logam $\mathrm{Na}^{+}$, $\mathrm{K}^{+}$, dan $\mathrm{Ca}^{2+}$ tidak akan berpengaruh terhadap aktivitas enzim katepsin D. Enzim katepsin D dari hepatopancreas sotong juga mengalami penurunan aktivitas dengan penambahan ion logam $\mathrm{Ba}^{2+}, \mathrm{Mn}^{2+}, \mathrm{Hg}^{2+}$ dan $\mathrm{Fe}^{3+}$.

Sadana et al. (2003) menyebutkan bahwa logam $\mathrm{Hg}^{2+}, \mathrm{Ca}^{2+}$, $\mathrm{Cu}^{2+}, \mathrm{Li}^{2+}, \mathrm{K}^{+}, \mathrm{Cd}^{2+}, \mathrm{Ni}^{2+}, \mathrm{Ba}^{2+}, \mathrm{Co}^{2+}$ dan $\mathrm{Sn}^{2+}$ dapat menghambat aktivitas enzim katepsin $L$ dari goat brain. Kerja enzim dapat dihambat oleh zat penghambat atau inhibitor. Inhibitor non-kompetitif tidak bersaing dengan substrat untuk berikatan dengan enzim. Inhibitor jenis ini akan berikatan dengan enzim pada sisi yang berbeda (bukan sisi aktif). Jika telah terjadi ikatan enzim-inhibitor, sisi aktif enzim akan berubah sehingga substrat tidak dapat berikatan dengan enzim. Banyak ion logam bekerja sebagai inhibitor non-kompetitif (Firmansyah et al. 2007). Beberapa enzim dan inhibitor memerlukan ion-ion tertentu untuk menjaga kestabilan aktivitasnnya, ion-ion tersebut dapat bertindak sebagai inhibitor pada kosentrasi tertentu, tetapi dapat juga menjadi aktivator pada kosentrasi berbeda. Ion logam dapat membentuk suatu komplek dengan subtrat dan sisi aktif enzim sehingga mengabungkan keduanya dan bentuk aktif. lon logam juga berfungsi sebagai senyawa penarik kuat elektron pada tahap tertentu dalam siklus katalitik (Lehninger, 1993).

\section{KESIMPULAN}

Enzim katepsin berhasil diekstraksi dari daging ikan patin. Ekstrak kasar enzim tersebut memiliki aktivitas sebesar 0.278 $\mathrm{U} / \mathrm{mL}$ dan aktivitas spesifik $0.907 \mathrm{U} / \mathrm{mg}$. Karakteristik ekstrak kasar enzim katepsin adalah sebagai berikut: memiliki suhu optimum $50^{\circ} \mathrm{C}, \mathrm{pH}$ optimum 6 , dan substrat optimum $2 \%$. Aktivitas enzim katepsin dipengaruhi oleh adanya ion logam. Ion logam $\mathrm{Fe}^{3+}, \mathrm{Cu}^{2+}, \mathrm{Mn}^{2+}, \mathrm{Ca}^{2+}$ menghambat aktivitas ekstrak 
kasar enzim katepsin, sedangkan ion $\mathrm{Mg}^{2+}$ meningkatkan aktivitas enzim tersebut.

\section{DAFTAR PUSTAKA}

Balti F, Hmidet N, Jellouli K, Nnedjar-Arroume N, Guillochon D, Nasri M. 2010. Cathepsin D from hepatopancreas of the cuttlefish (Sepia officinalis): purification and characterization. J Agr Food Chem 19: 10623-10630. DOI: 10.1021/jf102233d.

Campbell N. 2002. Biologi. Rahayu, penerjemah. Jakarta: Erlangga. Terjemahan dari: Biology.

Cunningham E, McCarthy E, Copley L, Jackson D, Johnson D, Dalton JP, Mulcahy G. 2010. Characterisation of cathepsin B-like cysteine protease of Lepeophtheiruss almonis. Aquaculture 310: 38-42. DOI: 10.1016/j.aquaculture.2010. 10.013.

Bradford MM. 1976. A rapid and sensitive method for quantification of microgram quantities of protein utilizing the principle of protein dye binding. Anal Biochem 72: 248-254. DOI: 10.1016/0003-2697(76) 90527-3.

Chen L, Sun L. 2012. Cathepsin B of Cynoglossussemilaevis: Identification, expression, and activity analysis. Comp Biochem Phys B 161: 54-59 DOI: 10.1016/j.cbpb.20 11.09 .008

Dinu D, Dumitru IF, Nechifor MT. 2002. Isolation and characterization of two chatepsin from muscle of Carassiusauratus gibelio. Rom Biotech Lett 7: 753-758.

Firmansyah R, Agus M, Umar R. 2007. Mudah dan Aktif Belajar Biologi. Bandung: Setia Purna Inves.

[KKP] Kementrian Kelautan dan Perikanan. 2011. Statistik Kelautan dan Perikanan 2009. Jakarta.
Krause J, Tshidino SC, Ogawa T, Watanabe Y, Oosthuizen V, Somai B, Muramoto K, Naude RJ. 2010. Purification and partial characterization of ostrich skeletal muscle cathepsin $\mathrm{D}$ and its activity during meat maturation. Meat Sci 87: 196201. DOI: 10.1016/j.meatsci.2010.10.009.

Ladrat DC, Cheret R, Taylor R, Bagnis VV. 2006. Trends in postmortem aging in fish: understanding of proteolysis and disorganization of the myofibrillar structure. Crit Rev Food Sci Nutr 46: 409-421.

Lehninger AL. 1993. Dasar-Dasar Biokimia Jilid 1. Jakarta: Erlangga. Terjemah dari : The Foundation of Biochemistry.

Sadana R, Mittal A, Khurana S, Singh H, Kamboj RC. 2003. Purification and characterization of the chatepsin L-like Proteinase from goat brain. Indian J Biochem Biophy 40: 315-323.

Suhartono MT. 1989. Enzim dan Bioteknologi. Bogor: Pusat Antar Universitas

Stoker HS. 2010. General, Organic, and Biological Chemistry. USA: Cengage Learning

Thammapat P, Raviyan P, Siriamorpon S. 2010. Proximate and fatty acids composition of muscles and viscera of asian catfish (Pangasiusbocourti). Food Chem 122: 223-227. DOI: 10.1016/j.foodchem.2010.02.065.

Whitaker JR. 1994. Principles of Enzymology for The Food Science. Second Edition. New York: Marcel Dekker, Inc.

Zhong C, Cai QF, Liu GM, Sun LC, Hara K, Su WJ, Cao MJ. 2012. Purification and characterisation of cathepsin $L$ from the skeletal muscle of blue scad (Decapterus maruadsi) and comparison of its role with myofibril-bound serine proteinase in the degradation of myofibrillar proteins. Food Chem 133: 1560-1568. DOI: 10.1016/j.foodchem.2012.02.050. 